\title{
Pelaksanaan Kegiatan Posyandu Balita pada Masa Pandemi Covid-19 sebagai upaya Pemenuhan Hak Balita sesuai dengan Peraturan Menteri Kesehatan No 4 Tahun 2019
}

\author{
Swasti Artanti, Pedvin Ratna Meikawati \\ Email: swasti.artanti@gmail.com \\ D III Kebidanan, Akademi Kebidanan Harapan Ibu Pekalongan, Indonesia \\ Jl. Sriwijaya No 7 Pekalongan \\ Telp. (0285) 4416108
}

\begin{abstract}
Abstrak
Kesehatan adalah Hak Azasi Manusia (HAM), sebagaimana diatur dalam UUD 1945 Pasal 28 H ayat (1) tentang Kesehatan yang berbunyi "Setiap orang berhak hidup sejahtera lahir dan batin, bertempat tinggal dan mendapatkan lingkungan hidup yang baik dan sehat serta berhak memperoleh pelayanan kesehatan". Kesehatan merupakan salah satu hak yang melekat dalam diri manusia. Pengertian kesehatan tertuang pada Pasal 1 ayat (1) Undang-Undang No 36 tahun 2009 tentang Kesehatan, kesehatan adalah keadaan sehat baik secara fisik, mental, spiritual maupun sosial yang memungkinkan setiap orang untuk hidup produktif secara sosial dan ekonomis. Kesehatan perlu diupayakan dan ditingkatkan oleh setiap individu dan seluruh komponen bangsa agar masyarakat dapat menikmati hidup sehat dan pada akhirnya mewujudkan derajat kesehatan masyarakat yang optimal. Posyandu merupakan salah satu bentuk Upaya Kesehatan Bersumber Daya Masyarakat (UKBM) yang dikelola dan diselenggarakan dari, oleh untuk dan bersama masyarakat dalam penyelenggaraan pembangunan kesehatan, guna memberdayakan masyarakat dan memberikan kemudahan kepada masyarakat dalam memperoleh pelayanan kesehatan dasar untuk mempercepat penurunan angka kematian ibu dan bayi. Tujuan dari penelitian ini adalah untuk mendeskripsikan pelaksanaan posyandu dalam pandemi covid-19 dan untuk mendeskripsikan upaya pemenuhan hak balita. Penelitian ini penelitian deskriptif analitis dengan pendekatan yuridis sosiologis, jenis data yang digunakan data primer dan data sekunder, dengan analisis kualitatif dari penelitian yuridis yang dilakukan dengan pendekatan sosiologis. Pengambilan sampel dengan teknik sampling jenuh dengan jumlah 42 ibu yang mempunyai balita 1-5 tahun. Instrumen yang digunkan menggunakan kuesioner. Berdasarkan hasil penelitian, sebagian besar anak yang melakukan kunjungan posyandu adalah usia 2-3 tahun yaitu sebanyak 22 anak $(52,4 \%)$, dengan pendidikan orang tua sebanyak 25 responden $(59,5 \%)$ dengan pendidikan sedang, didominasi oleh orang tua yang tidak bekerja yaitu sebanyak 28 anak $(66,7 \%)$. Dari hasil penelitian didapatkan kendala dalam pelaksanaan posyandu menunjukkan bahwa posyandu pesona desa rowobelang sesuai dengan protokol kesehatan. Namun, masih kurangnya kesadaran ibu-ibu balita untuk mematuhi protokol kesehatan seperti memakai masker dan tidak menjaga jarak. Diharapkan bagi orang tua yang memiliki anak usia 1-5 tahun agar tetap rutin membawa anaknya ke posyandu supaya pemenuhan hak balita dalam pelaksanaan kunjungan posyandu maksimal meskipun dengan tetap menerapkan protokol kesehatan untuk mengurangi angka kematian pada bayi dan balita.
\end{abstract}

Kata kunci: posyandu balita; hak balita; covid-19.

Abstract
Health is a human right for everyone, as regulated in the 1945 Constitution Article $28 \mathrm{H}$ paragraph
(1) concerning Health which states "Every person has the right to live in physical and spiritual
prosperity, to live and to have a good and healthy living environment and have the right to obtain
health services. " Health is one of the rights inherent in human beings. The definition of health is
stated in Article 1 paragraph (1) of Law No. 36 of 2009 concerning Health, health is a healthy 
Jurnal Kebidanan Harapan Ibu Pekalongan

condition both physically, mentally, spiritually and socially that allows everyone to live socially and economically productive. Health needs to be strived for and improved by every individual and all components of the nation so that people can enjoy a healthy life and ultimately realize an optimal degree of public health. Posyandu is one form of Community Based Health Efforts which is managed and organized from, by for and with the community in the implementation of health development, in order to empower the community and provide convenience to the community in obtaining basic health services to accelerate the reduction of maternal and infant mortality. The purpose of this study is to describe the implementation of posyandu in the covid-19 pandemic and to describe efforts to fulfill the rights of children under five. This research is an analytical descriptive study with a sociological juridical approach, the types of data used are primary data and secondary data, with a qualitative analysis of juridical research conducted with a sociological approach. Sampling with saturated sampling technique with the number of 42 mothers who have toddlers age 1-5 years. The instrument used is a questionnaire. Based on the results of, most of the children who visited the posyandu were aged 2-3 years, namely 22 children $(52.4 \%)$, with parental education as many as 25 respondents $(59.5 \%)$ with moderate education, dominated by people parents who do not work as many as 28 children (66.7\%). From the results of the study, it was found that the obstacles in the implementation of the posyandu showed that the Posyandu Pesona in Rowobelang Village was in accordance with the health protocol. However, mothers of toddlers still lack awareness to comply with health protocols such as wearing masks and not keeping a distance. It is hoped that parents who have children aged 1-5 years continue to regularly bring their children to the posyandu so that the fulfillment of the rights of toddlers in carrying out posyandu visits is maximized even though they continue to apply health protocols to reduce infant and toddler mortality. maternal and infant mortality. The purpose of this study was to determine the relationship between mother's level of knowledge and age of toddlers with visits by mothers with toddlers to the new normal era posyandu in Pekalongan city. This research was conducted using a descriptive correlative research method with a cross sectional approach, sampling with a saturated sampling technique with a total of 37 mothers who have toddlers 1-5 years. The instrument used was a questionnaire sheet and the analysis used was Chi Square statistical test. Based on the results of univariate analysis, most of the children who visited the posyandu were aged 3 years, namely 10 children $(31.2 \%)$, with parental education as many as 22 respondents $(68.8 \%)$ having higher education (PT), dominated by working parents as many as 24 children (75\%). A total of 25 respondents (78.1\%) visited the posyandu regularly and most of the respondents had a good level of knowledge, as many as 29 respondents $(20 \%)$. The results of the bivariate analysis showed that there was no relationship between children's age and posyandu visits ( $p$ value 0.217$)$ and there was a relationship between parents' knowledge level and posyandu visits ( $p$ value 0.002). It is hoped that parents who have children aged 1-5 years will continue to routinely bring their children to the posyandu in the new normal era even though they still apply health protocols.

Keywords: toddler posyandu; toddler rights; covid-19 pandemic.

\section{Pendahuluan}

Kesehatan adalah Hak Azasi Manusia (HAM), sebagaimana diatur dalam UUD 1945 Pasal $28 \mathrm{H}$ ayat (1) tentang Kesehatan yang berbunyi "Setiap orang berhak hidup sejahtera lahir dan batin, bertempat tinggal dan mendapatkan lingkungan hidup yang baik dan sehat serta berhak memperoleh pelayanan kesehatan" [ $\left.{ }^{1}\right]$. Kesehatan merupakan salah satu hak yang melekat dalam diri manusia. Pengertian kesehatan tertuang pada
Pasal 1 ayat (1) Undang-Undang No 36 tahun 2009 tentang Kesehatan, kesehatan adalah keadaan sehat baik secara fisik, mental, spiritual maupun sosial yang memungkinkan setiap orang untuk hidup produktif secara sosial dan ekonomis. Kesehatan perlu diupayakan dan ditingkatkan oleh setiap individu dan seluruh komponen bangsa agar masyarakat dapat menikmati hidup sehat dan pada akhirnya mewujudkan derajat 
Jurnal Kebidanan Harapan Ibu Pekalongan

kesehatan masyarakat yang optimal $\left[{ }^{2}\right]$.

Posyandu merupakan salah satu bentuk Upaya Kesehatan Bersumber Daya Masyarakat (UKBM) yang dikelola dan diselenggarakan dari, oleh untuk dan bersama masyarakat dalam penyelenggaraan pembangunan kesehatan, guna memberdayakan masyarakat dan memberikan kemudahan kepada masyarakat dalam memperoleh pelayanan kesehatan dasar untuk mempercepat penurunan angka kematian ibu dan bayi (Zulkili, 2003) $\left[{ }^{3}\right]$.

Posyandu sangat berperan dalam peningkatan kesehatan dimasyarakat khususnya ibu dan balita. Manfaat dari posyandu adalah meningkatkan kemitraan dan pemberdayaan masyarakat untuk kesinambungan kegiatan posyandu (Ridwan, 2007) [ $\left.{ }^{4}\right]$. Salah satu tujuan posyandu adalah memelihara dan meningkatkan kesehatan bayi, balita, ibu hamil dan pasangan usia subur. Pemantauan pertumbuhan merupakan kegiatan utama posyandu.

Kegiatan posyandu dilaksanakan setiap sebulan sekali pada minggu ke 3 yang kegiatannya dilakukan disalah satu rumah warga, dalam pelaksanaan kegiatan posyandu yaitu berbeda dengan pada waktu normal dan non normal. Pada masa pandemi yang terjadi sekarang keikutsertaan masyarakat berkurang dikarenakan banyak masyarakat yang cemas akan perkumpulan. Namun, akhir-akhir ini beberapa posyandu terpaksa harus dihentikan agar meminimalkan penyebaran virus covid-19. Virus covid-19 adalah virus jenis baru dari coronavirus (kelompok virus yang menginfeksi sistem pernafasan). Covid-19 awalnya ditularkan dari hewan ke manusia. Setelah itu, diketahui bahwa infeksi ini juga bisa menular dari manusia ke manusia. Dengan penularannya yang sangat mudah maka hal tersebut juga menghambat kegiatan umum salah satunya posyandu.

Menurut Peraturan Menteri Kesehatan No 4 Tahun 2019, Standar Teknis Pemenuhan mutu pelayanan dasar pada standar pelayanan minimal bidang kesehatan yang selanjutnya disebut SPM Kesehatan merupakan ketentuan mengenai Jenis dan Mutu Pelayanan Dasar yang merupakan urusan Pemerintah Wajib yang berhak diperoleh setiap warga secara minimal $\left[{ }^{5}\right]$. Posyandu sebagai sarana belajar masyarakat seyogyanya sudah menjadi kegiatan rutin dimasyarakat. Namun demikian, kondisi sosial masyarakat selama masa pandemi Covid-19 ini cukup berpengaruh terhadap palayanan kesehatan khususnya posyandu sebab seluruh konsentrasi pelayanan kesehatan bayi dan balita tertuju pada Covid-19, oleh karena itu pembina posyandu dalam hal ini puskesmas tetap harus mendorong posyandu untuk aktif dalam memberikan pelayanan kesehatan bayi dan balita dengan tetap memperhatikan protokol kesehatan masyarakat. Posyandu ini merupakan wadah titik temu antara pelayanan profesional dari petugas kesehatan dan peran serta masyarakat dalam menangani masalah kesehatan masyarakat, terutama dalam upaya penurunan angka kematian bayi dan angka kematian balita.

Maka penulis tertarik untuk melakukan penelitian pelaksanaan posyandu dalam pandemi covid-19 di Posyandu Pesona Desa Rowobelang Kabupaten Batang yang bertujuan (1) mendeskripsikan pelaksanaan posyandu dalam pandemi covid-19 di Posyandu Pesona Desa Rowobelang Kabupaten Batang, mendeskripsikan upaya pemenuhan hak balita.

Manfaat dari hasil penelitian ini dapat memberi manfaat bagi 
Jurnal Kebidanan Harapan Ibu Pekalongan

pemerintah desa, puskesmas, kecamatan, lintas sektor dan dinas terkait dalam meningkatkan pelaksanaan posyandu dan dapat bermanfaat bagi pengembangan ilmu kebijakan publik dan pelayanan publik.

Berdasarkan Keputusan Menteri Kesehatan Nomor 1529 Tahun 2010 tentang Pedoman Umum Pengembangan Desa dan Keluarga Siaga Aktif bahwa keaktifan posyandu merupakan salah satu kriteria untuk mencapai Desa dan Kelurahan yang siaga aktif $\left[{ }^{6}\right]$. Maka dari itu Kementrian Kesehatan Republik Indonesia harus memiliki solusi agar tetap dilaksanakan posyandu dimasa pandemi covid-19. Salah satu solusi dalam permasalahan tersebut sehingga adanya Petunjuk Teknis Buku Panduan Pelayanan Kesehatan Balita Pada Masa Tanggap Darurat Covi-19 yang diterbitkan oleh Kementrian Kesehatan Republik Indonesia agar posyandu tetap berjalan dengan mematuhi protokol kesehatan. Berdasarkan uraian diatas, maka penulis tertarik melakukan penelitian dengan judul "Pelaksanaan Kegiatan Posyandu Balita Pada Masa Pandemi Covid-19 Sebagai Upaya Pemenuhan Hak Balita Sesuai Dengan Peraturan Menteri Kesehatan No 4 Tahun 2019 Di Posyandu Pesona Desa Rowobelang Kecamatan Batang Kabupaten Batang".

\section{Metode Penelitian}

Penelitian ini merupakan penelitian deskriptif analitis dengan pendekatan yuridis sosiologis, jenis data yang digunakan data primer dan data sekunder, dengan analisis kualitatif dari penelitian yuridis yang dilakukan dengan pendekatan sosiologis. Waktu yang penelitian bulan Oktober-Desember 2020.

Penelitian ini dilakukan di Posyandu Pesona Desa Rowobelang $\begin{array}{lrr}\text { Kabupaten } & \text { Batang. } & \text { Instrumen } \\ \text { pengumpulan } & \text { data } & \text { dengan }\end{array}$ menggunakan wawancara mendalam dan observasi. Pengambilan sampel dengan teknik sampling jenuh dengan jumlah 42 ibu yang mempunyai balita 1-5 tahun. Wawancara yang dilakukan oleh kader posyandu, ibu yang mempunyai balita, tenaga kesehatan. Instrumen pengumpulan data dengan menggunakan wawancara mendalam. Wawancara yang dilakukan kepada kader posyandu, ibu yang mempunyai balita dan tenaga kesehatan. sedangkan data sekunder diperoleh dengan melakukan studi dokumentasi serta studi pustaka.

\section{Hasil dan Pembahasan}

Posyandu merupakan pusat kesehatan dasar bagi balita. Posyandu dituntut mampu menyediakan informasi kesehatan secara lengkap sehingga menjadi sentra kegiatan kesehatan masyarakat. Keadaan posyandu sudah menjadi hal yang penting ditengah masyarakat selain berfungsi sebagai wadah pemberdayaan masyarakat juga mendekatkan pelayanan dasar bidang kesehatan terutama berkaitan dengan penurunan angka kematian bayi dan angka kematian balita.

a. Karakteristik Responden Berdasarakan Usia Anak

Tabel 2.1. Distribusi Responden

\begin{tabular}{lcc}
\multicolumn{3}{c}{ Berdasarkan Usia Anak } \\
\hline $\begin{array}{l}\text { Umur } \\
\text { (bulan) }\end{array}$ & Jumlah & $\mathbf{( \% )}$ \\
\hline 0-1 tahun & 8 & 19 \\
2-3 tahun & 22 & 52,4 \\
4-5 tahun & 12 & 28,6 \\
\hline Jumlah & 42 & 100 \\
\hline
\end{tabular}

Berdasarkan tabel 2.1. hasil dari penelitian menunjukkan bahwa sebagaian besar usia anak yang melakukan kunjungan posyandu adalah usia 2-3 tahun yaitu sebanyak 22 anak $(52,4 \%)$, 
Jurnal Kebidanan Harapan Ibu Pekalongan

usia 0-1 tahun 8 anak (19\%), dan usia 4-5 tahun sebanyak 12 anak sebanyak $(28,6 \%)$.

Berdasarkan distribusi frekuensi usia anak menunjukkan sebagaian besar usia anak yang melakukan kunjungan ke posyandu Pesona Desa Rowobelang Kecamatan Batang Kabupaten Batang sebanyak $(52,4 \%)$. Umur anak dibawah 5 tahun, merupakan masa keemasan (golden age), diharapakan mereka para balita berkembang sesuai dengan tumbuh kembangnya mereka agar terpantau dan berjalan dengan baik. Menurut Maharsi R (2007) dalam penelitiannya bahwa ibu merasa perlu membawa balitanya ke posyandu pada usia $<12$ bulan (masa pemberian imunisasi) sedangkan balita sampai umur 5 tahun untuk menimbang agar terpantau tumbuh kembanganya balita yang biasanya sering dianggap sesuatu yang tidak penting $\left[{ }^{7}\right]$.

b. Karakteristik Responden Berdasarkan Tingkat Pendidikan Orang Tua

Tabel 2.2 Distribusi Responden Berdasarkan Tingkat Pendidikan Orang Tua

\begin{tabular}{|c|c|c|}
\hline Berat badan & Jumlah & $(\%)$ \\
\hline $\begin{array}{l}\text { Rendah (SD, } \\
\text { SLTP) }\end{array}$ & 7 & 16,7 \\
\hline $\begin{array}{l}\text { Sedang } \\
\text { (SMA) }\end{array}$ & 25 & 59,5 \\
\hline Tinggi $(\mathrm{PT})$ & 10 & 23,8 \\
\hline Jumlah & 42 & 100 \\
\hline
\end{tabular}

Berdasarkan tabel 2.2 hasil dari penelitian menunjukkan bahwa sebagaian besar responden yang memiliki pendidikan rendah sabanyak 7 responden $(16,7 \%)$, yang memiliki pendidikan sedang sebanyak 25 responden $(59,5 \%)$ dan pendidikan tinggi sebanyak
10 responden $(23,8 \%)$.

Berdasarkan distribusi frekuensi pendidikan orang tua menunjukkan bahwa pendidikan orang tua balita di Posyandu Pesona Desa Rowobelang Kecamatan Batang Kabupaten Batang didapatkan mayoritas pendidikan responden yaitu pendidikan sedang (SMA) (59,5\%).

Ibu yang berpendidikan SMA menyakini pentingnya membawa balitanya berkunjung ke posyandu untuk memantau pertumbuhan dan perkembangannya dalam upaya pentingnya pelayanan kesehatan (Maryunani, 2010) $\left[{ }^{8}\right]$.

c. Karakteristik Responden Berdasarkan Pekerjaan Orang Tua

Tabel 2.3 Distibusi Responden Berdasarkan Pekerjaan Orang Tua

\begin{tabular}{lcc}
\hline Berat badan & Jumlah & $\mathbf{( \% )}$ \\
\hline Bekerja & 14 & 33,3 \\
Tidak & 28 & 66,7 \\
Bekerja & & \\
\hline Jumlah & 42 & 100 \\
\hline
\end{tabular}

Berdasarkan tabel 2.3 hasil dari penelitian menunjukkan bahwa sebagaian besar anak memiliki orang tua yang tidak bekerja yaitu sebanyak 28 anak $(66,7 \%)$ dan 14 anak (33,3\%) yang memiliki orang tua yang tidak bekerja.

Kegiatan posyandu yang dilakukan pada pagi hari sehingga kebanyakan ibu yang mengunjungi posyandu berstatus tidak bekerja. Ibu yang bekerja, terikat oleh jam kerja sehingga ibu tidak dapat membawa balitanya ke posyandu pada hari jam kerja. Ibu yang tidak bekerja mempunyai waktu luang lebih besar dalam memberikan perhatian kepada anaknya dengan 
Jurnal Kebidanan Harapan Ibu Pekalongan

membawa anaknya ke posyandu (Maulana, 2013) [ $\left.{ }^{9}\right]$.

d. Kendala Pelaksanaan Posyandu Dalam Upaya Pemenuhan Hak Balita Atas Kesehatan Pada Masa Pandemi Covid -19

Anak merupakan tahap perkembangan hidup manusia baik ditinjau secara fisik maupun psikis. Penjelasan tentang fisik biasanya mengacu pada usia sedangkan psikis biasanya berdasarkan kemampuan psikologis mengacu pada kemampuan nalar (rasio) dan perilaku (behavior).

Hasil dari obeservasi penelitian menunjukkan bahwa hampir disetiap pelaksanaan kegiatan di posyandu pesona desa rowobelang bahwa masyarakat pada pelaksanaan posyandu terutama orang tua balita masih belum bisa menerapkan protokol kesehatan dengan baik, misalnya: menjaga jarak 1 meter pada antri dengan pasien lain hal tersebut karena tempat kurang memadai.

Salah satu bentuk terwujudnya pemenuhan hak atas kesehatan pada balita melalui program penyuluhan kesehatan dengan mengunjungi posyandu apabila kader memberikan penyuluhan dan pendidikan kesehatan kepada ibu balita tentang kesehatan anak, memantau pertumbuhan dan perkembangan anak.

Pembinaan kepada kader dilakukan oleh bidan dan tenaga kesehatan dengan melakukan pertemuan sebulan sekali dalam rangka membahas kegiatan pelaksanaan posyandu.

Menurut peneliti berdasarkan program posyandu yang telah dilaksanakan di posyandu pesona Desa Rowobelang sudah tergolong lengkap dan sesuai dengan Kementrian Kesehatan Republik Indonesia karena dalam pelaksanaanya terdapat fasilitas penunjang penerapan protokol Kesehatan yang meliputi tempat cuci tangan atau hand sanitizer, alat ukur suhu tubuh dan face shield yang digunakan oleh bidan atau petugas Kesehatan. Posyandu Pesona yang sudah dilaksanakan sesuai dengan Buku Petunjuk Teknis Pelayanan Imunisasi Pada Masa Pandemi Covid-19 merupakan usaha untuk tercapainya pemenuhan hak balita yang harus mereka dapatkan guna untuk mengurangi angka kematian pada balita dan merupakan tujuan dari diterapkannya posyandu.

e. Implementasi Peraturan Dalam Upaya Pemenuhan Hak Balita Atas Kesehatan

1) Hak Atas Kesehatan Balita Di Posyandu

Pelayanan kesehatan dasar di posyandu merupakan bagian dari upaya pemenuhan hak atas kesehatan kepada balita. Sebagaimana yang merupakan bentuk dari perlindungan pemerintah Indonesia kepada rakyatnya termasuk pada balita yakni pada Pasal $28 \mathrm{H}$ Ayat (1) Undang-Undang Dasar 1945 yang menyebutkan bahwa "Setiap orang berhak hidup sejahtera lahir dan batin, bertempat tinggal, dan mendapatkan lingkungan hidup yang baik dan sehat serta berhak memperoleh pelayanan kesehatan" $\left.{ }^{10}\right]$.

Setiap balita memiliki hak sejak mulai dari dalam kandungan, dilahirkan hingga tumbuh berkembang. Dengan kondisi yang masih sangat lemah, balita wajib mendapatkan perlindungan 
Jurnal Kebidanan Harapan Ibu Pekalongan

oleh negara dengan adanya peraturan bahwa setiap anak memiliki hak untuk dapat hidup, tumbuh dan berkembang dengan memperhatikan kesehatan dan tumbuh kembangnya. Peran posyandu sebagai bentuk peran kerjasama pemerintah dengan masyarakat, sangat membantu dalam memberikan informasi dan pelayanan kesehatan kepada ibu dan balita.

Hubungan antara Tenaga Kesehatan yaitu Kader dengan pasien adalah hubungan hukum, karena masing-masing merupakan subyek hukum serta hak dan kewajiban dalam hukum dan persamaan kedudukan hukum bagi setiap orang. Hubungan tersebut bisa terjadi manakala pasien membutuhkan pada waktu kegiatan posyandu. Jika ada ketidakpuasan atau permasalahan maka akan timbul akibat hukum.

Terkait dengan hal tersebut maka pemenuhan hak balita sesuai dengan Peraturan Menteri Kesehatan Republik Indonesia No 25 Tahun 2014 Tentang Upaya Kesehatan Anak dimana adanya pelayanan kesehatan tingkat desa atau dusun yang dilakukan dengan mengacu pada buku petunjuk teknis yang menjadi solusi tetap terlaksananya posyandu dengan tanda kutip disesuaikan dengan Protokol Kesehatan guna meminimalisir penyebaran virus Covid-19 $\left[{ }^{11}\right]$.

2) Implementasi Peraturan Dalam Upaya Pemenuhan Hak Atas
Kesehatan Pada Balita Di
Posyandu

Posyandu merupakan salah satu wadah komunikasi kesehatan dimasyarakat dalam pelayanan kesehatan yang bersumber daya masyarakat dalam rangka pemenuhan kesehatan pada ibu hamil, ibu nifas, balita sampai dengan lansia untuk menurunkan angka kematian dan kesakitan pada ibu dan anak.

Pada posyandu kader adalah seseorang tenaga yang secara sukarela yang direkut dari oleh dan untuk masyarakat yang bertugas membantu kelancaran pelayanan kesehatan dan bersedia menggerakan masyarakat untuk melaksanakan dan mengikuti kegiatan posyandu. Kader juga mempunyai peran dalam menentukan keberhasilan pencapaian program posyandu yang terintragrasi yang berasal dari posyandu.

Hal ini sesuai dengan Pasal 1 angka 12 Peraturan Menteri Kesehatan No 25 Tahun 2014 Tentang Upaya Kesehatan Anak menyebutkan bahwa: “ kader adalah setiap orang yang dipilih oleh masyarakat dan dilatih untuk menangani masalah-masalah kesehatan perorangan atau masyarakat serta bekerja dalam hubungan yang amat dekat dengan tempat-tempat pemberian pelayanan kesehatan".

Dalam posyandu, kader yang aktif mempunyai motivasi kepada ibu balita untuk terus mengikuti dan membawa anaknya datang ke posyandu yang diadakan setiap satu bulan sekali dengan 
Jurnal Kebidanan Harapan Ibu Pekalongan

memberikan reward ke ibu balita apabila dalam setahun mampu mengikuti posyandu delapan kali.

\section{Kesimpulan}

Berdasarkan landasan teori dan didukung oleh hasil uji stastistik penelitian, maka dapat disimpulkan bahawa usia anak yang melakukan kunjungan posyandu menunjukkan sebagian besar memiliki usia 3 tahun yaitu sebanyak 10 anak $(31,2 \%)$. Karakteristik responden menunjukkan sebagian besar pendidikan orang tua adalah Perguruan Tinggi (68,8\%), dengan orang tua yang bekerja (75\%), sebagian besar melakukan kunjungan posyandu dengan rutin $(78,1 \%)$ dan hampir semua orang tua memiliki pengetahuan yang baik $(90,6 \%)$.

Tidak terdapat hubungan antara usia anak dengan kunjungan posyandu era new normal dengan nilai $\mathrm{p}$ value $0,217>0,05$. Terdapat hubungan antara tingkat pengetahuan orang tua dengan kunjungan posyandu era new normal dengan nilai $p$ value $0,002<$ 0,05 .

\section{Daftar Pustaka}

[1]. UUD 1945 Pasal $28 \mathrm{H}$ ayat (1) tentang Kesehatan.

[2]. Zulkifli, "Posyandu dan Kader Kesehatan," [Online]. Available:

http://repository.usu.ac.id/bitstr eam/handle/123456789/3753/fk m-

zulkifli1.pdf;jsessionid=71D1C 3A8C9D9EDB5CDDD1C7B81 590C73? sequence $=1$. (accesss Agus. 31, 2020)

[3]. Ridwan dkk, "Revitalisasi Posyandu Pengaruhnya Terhadap Kinerja Posyandu di Kabupaten Tenggamus." http//www. KMPK Working Paper Seris No16 juli 2007.pdf (access Sept. 13, 2009)
[4]. A. W. G. Fitri, "Peran kelompok bermain dalam proses sosialisasi anak usia dini di Kecamatan Sukorejo Kabupaten Kendal. Semarang: Universitas Negeri Semarang," J. Digilib Unnes, 2015.

[5]. Nazri C. et.al, Factors influencing mother"s participation in Posyandu for improving nutritional status of children under-five in Aceh Utara district, Aceh province, Indonesia. BMC Public Health, 2016.

[6]. D. Reihana and B. S. Artha, "Faktor-Faktor Yang Berhubungan Dengan Partisipasi Ibu Untuk Menimbang Balita ke Posyandu Factors Associated with Maternal Participation for Weighing Toddler at Integrated Health Post (Posyandu)," $J$. Kedokt. Yars., vol. 20, no. 3, pp. 143-157, 2012.

[7]. S. Notoatmodjo, Promosi Kesehatan dan Perilaku Kesehatan. Jakarta: Rineka Cipta, 2010.

[8]. D. N. H. A. Nugroho, "Hubungan antara Pengetahuna dan Motivasi Kader Posyandu dengan Keaktifan Kader POSYANDU di Desa Dukuh Tengah Kecamatan Ketanggungan Kabupaten Brebes," Fikkes J. Keperawatan, vol. 2, no. 1, pp. 1-8, 2008.

[9]. S. P. H. DJaiman, "Faktorfaktor yang Mempengaruhi Balita Berkunjung ke Posyandu." http//www.Research Report ITB pdf. (access Sept. 12, 2020) 
Jurnal Kebidanan Harapan Ibu Pekalongan

[10]. Husnaini, Hubungan Antara Karakteristik Ibu Balita dengan Kunjungan Balita dalam Kegiatan Posyandu di Keluarahan Genuksari Kecamatan Genuk Kota Semarang. 2013.

[11]. W. Mubarak, Ilmu kesehatan Masyarakat dan Pemanfaatan Posyandu. Jakarta: Rineka Cipta, 2012.
[12]. Wahyuni and Dkk, Hubungan Jumlah Kunjungan Posyandu Dengan Status Gizi Balita (15tahun). 2019. 